\title{
ИТОГИ ВЫБОРОВ В ЕВРОПАРЛАМЕНТ 2019 Г. В СЕВЕРНЫХ СТРАНАХ: СТАТИСТИКА
}

\begin{abstract}
Аннотация. Выборы в Европарламент оказали определённое влияние на страны Северной Европы: Швецию, Финляндию и Данию. Экономическое положение северных стран в 2019 г. является в целом благоприятным фоном для этих выборов. Несмотря на малонаселенность и небольшое количество мест, которое северные страны имеют в Европарламенте, выборы стали поводом для активизации внутриполитических сил. Стабильными можно назвать результаты выборов в Финляндии, наибольшие изменения произошли в Дании.
\end{abstract}

Ключевые слова: выборы, Европарламент, Швеция, Финляндия, Дания.

Прошло пять лет со времени предыдущих выборов в Европарламент в мае 2014 г. В Швеции в этот период дважды состоялись выборы в риксдаг. Если на выборах 2014 г. победили социал-демократы, то после выборов 2018 г. они смогли остаться у власти только в результате многомесячных переговоров с другими политическими силами. Дважды прошли выборы в парламент Финляндии.

Выборы в Европарламент для северных стран имеют достаточно скромное значение. Мизерное количество мест в ЕП при весьма малом населении (в Швеции - свыше 10 млн человек, в Финляндии и Дании - свыше 5 млн) не позволяет этим странам оказывать какое-либо заметное влияние в Европарламенте, где доминируют страны-тяжеловесы - ФРГ, Франция, Италия, Испания, Польша. Поэтому предполагалось, что интерес к этим выборам будет не слишком велик в северных странах. Однако это не совсем так.

Для выборов в Европарламент характерны несколько особенностей. Во-первых, это более низкая явка избирателей. Во-вторых, это усиление протестного голосования, т.е. растёт популярность оппозиционных (особенно с правой стороны) партий, возрастает доля голосов, поданных за евроскептиков и популистов. В-третьих, это недостаток дискуссий по общеевропейской тематике - выборы обычно проходят в контексте национальной проблематики. И в этом отношении кардинальных изменений накануне выборов в ЕП не предвиделось.

Опросы населения в странах Северной Европы дают достаточно точное представление о настроениях в них по отношению к ЕС. Примечателен опрос жителей северных стран, который прошёл 22 ноября 2018 г. и был опубликован в Евробарометре. Доверие к ЕС высказали $52 \%$ в Финляндии, $59 \%$ в Швеции и $60 \%$ в Дании, а недоверие - $31 \%$ в Дании, $34 \%$ в Швеции и $36 \%$ в Финляндии. Доверие к национальному парламенту высказали от $61 \%$ в Дании до $73 \%$ в Швеции, а к правительству - от 52\% в Дании до $60 \%$ в Швеции. Положительное отношение к ЕС выразили 53\% шведов, 48\% датчан и лишь 40\% финнов, нейтральное - 44\% финнов, $36 \%$ датчан и $33 \%$ шведов, а отрицательное - 14-15\% опрошенных.

Далее следовали вопросы об отношении к отдельным сторонам деятельности ЕС. Поло-

\footnotetext{
(C) Волков Алексей Михайлович - кандидат экономических наук, заведующий сектором экономики европейских стран Центра европейских исследований Национального исследовательского института мировой экономики и международных отношений им. Е.М. Примакова РАН. Адрес: 117997, Россия, Москва, ул. Профсоюзная, д. 23. E-mail: volkov@imemo.ru.
}

DOI: http://dx.doi.org/10.15211/vestnikieran320193035 
жительное отношение к свободному перемещению граждан высказали от 78 до 92\%, к общей политике в области безопасности и обороны - от 64 до 72\%, к общей энергетической политике - от 65 до $73 \%$, к общей торговой политике - от 71 до $73 \%$, к общей политике в области миграции - от $56 \%$ в Финляндии, $60 \%$ в Дании до $76 \%$ в Швеции, к общей внешней политике от 43 до 50\%. Показательно также отношение жителей северных стран к Европейской валютной системе и единой валюте евро. Если входящие в зону евро финны высказали подавляющее положительное отношение к ней $-82 \%$, то лишь меньшинство не входящих в зону евро датчан и шведов положительно относились к ней - 30 и 29\% соответственно. Меньшинство, но уже во всех трёх странах, высказалось за дальнейшее расширение ЕС - от $28 \%$ в Финляндии и $32 \%$ в Дании до 44\% в Швеции. Соответственно, отрицательное отношение было высказано по отношению к евро в Швеции (65\%) и Дании $(61 \%)$ и расширению ЕС в Финляндии (64\%) и Дании (51\%). На вопрос «Чувствуете ли Вы себя гражданами ЕС?» положительно ответили от 78 до $82 \%$, «Хотите ли Вы знать больше о правах граждан ЕС?»- от 58 до 72\% (Швеция), «Знаете ли Вы, какие права есть у граждан ЕС?»- от 58\% в Дании до 73\% в Финляндии.

Вопрос о положительных результатах деятельности ЕС (допускалось два ответа). Свободное перемещение людей, товаров и услуг в ЕС считали важнейшим результатом от $61 \%$ в Дании до 72\% в Швеции, мир между членами ЕС - от 64\% в Финляндии до 76\% в Швеции, евро - от 7\% в Дании и $8 \%$ в Швеции до $42 \%$ в Финляндии, программу обмена студентами (ЭРАСМУС) - от $18 \%$ в Дании до $24 \%$ в Швеции, экономическую мощь ЕС - от $8 \%$ в Финляндии до $12 \%$ в Швеции и Дании, политическое и экономическое влияние ЕС в мире - от $27 \%$ в Финляндии до $41 \%$ в Швеции, уровень социального благосостояния (здравоохранение, образование, пенсии) в ЕС - от 19\% в Швеции до 36\% в Дании, единую сельскохозяйственную политику - от 4\% в Финляндии до 11\% в Дании.

Жители северных стран проявили хорошую осведомлённость о европейских делах - от $53 \%$ в Швеции до 62\% в Дании. На вопрос - «Откуда Вы узнаете новости о европейской политических делах?»- респонденты ответили так: телевидение - от $71 \%$ в Швеции до $80 \%$ в Дании, интернет - от 49\% в Швеции до 62\% в Финляндии, печатная пресса - от $61 \%$ в Финляндии до $37 \%$ в Дании, радио - от $33 \%$ в Финляндии до 50\% в Швеции и Финляндии, социальные сети - от $16 \%$ в Швеции и Финляндии до $26 \%$ в Дании.

Таким образом, можно сделать вывод, что граждане северных стран не только активно интересуются национальными проблемами, но и находятся в курсе событий, происходящих в Евросоюзе.

Одним из политических факторов стало стремление властей оградить электорат от иностранного влияния. Так, шведские власти начали работать над этим в преддверии выборов в Европарламент, о чём шведское новостное радио Ekot coобщило 3 апреля. Особое внимание соответствующих органов было направлено на Соединённые Штаты Америки. Как заявил Бен Ниммо, один из крупнейших мировых экспертов в области дезинформации и руководитель отделения Digital Forensic Research Lab Атлантического совета, в последние годы наблюдались попытки определённых праворадикальных групп из США наладить сотрудничество со шведскими правыми. Речь шла о разжигании ненависти к исламу и к иммигрантам. При этом правые перенимают пресловутые «русские методы» распространения дезинформации. Соответствующая работа проводится в Швеции в связи с тем, что многочисленные попытки повлиять на мнение избирателей были выявлены незадолго до выборов в риксдаг осенью 2018 г. Руководит этой работой Шведское агентство по гражданским непредвиденным обстоятельствам. 
По данным финской службы новостей Yle (yle.fi) от 11 февраля 2019 г., согласно опросу, проведённому Ассоциацией печатной прессы, каждый третий финн верит в то, что сторонние силы будут пытаться повлиять на исход грядущих парламентских евровыборов. При этом Финляндия готовится защищаться от российского вмешательства в выборы. По словам министра юстиции Финляндии Аннти Хяккянена, Москва всеми средствами стремится посеять недоверие по отношению к целому ряду политических деятелей Финляндии с целью наращивания в ЕС антиевропейских настроений (Bloomberg, 28 марта 2019 г.). Речь идёт о кибератаках, а также о «фейковых» аккаунтах в социальных сетях, например в сети «Facebook», которые распространяют дезинформацию.

26 мая 2019 г. состоялись девятые всеобщие и прямые выборы в Европарламент. От Швеции избиралось 20 депутатов, от Финляндии и Дании - по 13 (после брекзита каждая из этих стран может получить по одному дополнительному месту). Всего избирался 751 депутат, в том числе в совокупности из стран Северной Европы - 46. Для того чтобы попасть в Европарламент, партии необходимо преодолеть барьер в 5\% голосов (в Швеции, как и в риксдаг $4 \%)$.

Характерной для выборов в Европарламент в 2019 г. стала повышенная явка избирателей, причём это произошло в большинстве стран ЕС, в том числе и в северных. Это объясняется тем, что на предыдущих выборах интерес к ним был намного ниже, что в этот раз. Представляется, что к избирателям приходит всё большее осознание того, что происходит дальнейшее углубление интеграции, а единственным органом, через который можно каким-то образом контролировать этот процесс, является Европейский парламент.

Особенностью выборов в северных странах является относительное постоянство волеизъявления электората. Только одна партия в трёх странах - Датская народная партия - потеряла большинство своих сторонников, что объясняется тем, что на предыдущих выборах она получила значительное количество голосов благодаря своей антииммигрантской риторике, которая в 2019 г. была не столь актуальной. Значительная часть электората северных стран голосует за «свои» партии, но накануне выборов позиция трети избирателей остаётся неопределённой.

В Швеции в 2014 г. социал-демократы имели 24,2\% голосов на выборах в Европарламент. Однако общая динамика имела некоторую тенденцию к снижению. Что касается выборов в Европарламент, то социал-демократы хотели завоевать ещё один, шестой мандат. Для того чтобы достичь этой цели, представители партии хотели лично поговорить с 500 тыс. избирателями, в том числе с 400 тыс., пройдя по квартирам. У их основных конкурентов - умеренно-коалиционной партии - та же самая динамика с учётом того, что их бывшие союзники по Альянсу оказали поддержку социал-демократам в деле формирования нового правительства.

Напротив, поддержка ультраправой партии «Демократы Швеции» непрерывно росла, особенно в связи с их критикой миграционной политики в стране. Правда, роль этой тематики во внутриполитических дискуссиях стала снижаться.

Партия охраны окружающей среды - «зелёные» получила на выборах в Европарламент намного больше голосов, чем на выборах в риксдаг. Правда, тогда она была в оппозиции, а сейчас входит в правительство. Предполагалось, что она получит намного больше голосов, чем на выборах в риксдаг, но всё же меньше, чем было на прошлых выборах в ЕП. В пользу «зелёных» был их акцент на экологической политике, которую шведы ставят высоко по сравнению с другими сферами, которые предстоит затрагивать партиям в Европарламенте.

Пёстрая картина у более мелких партий. Динамика Левой партии, которую социал-демократы по существу игнорируют как союзника, но не прочь в некоторых случаях опираться на 
её мандаты в риксдаге, показывала увеличение влияния. Росло влияние христианско-демократической партии и Партия центра, а вот либералы теряли свои голоса. Ожидалось, что Феминистская инициатива вряд ли повторит свой успех 5-летней давности.

Согласно опросам, за полторы недели до выборов лидировали социал-демократы $(21,9 \%)$, за ними вплотную следовали Демократы Швеции (19,9\% с прибавкой в 3\% за неделю). За Левую партию собирались голосовать 9,5\% (+2,1\%), а доля Умеренно-коалиционной партии снизилась с $15,5 \%$ до $13,5 \%$.

Однако прогнозы оказались неточными. В 2019 г. в Швеции победили, как и всегда, социал-демократы с 23,6\% голосов и 5 местами, за ней следовали Умеренно-коалиционная партия (16,8\% и 4), Демократы Швеции (15,4\% и 3), зелёные (11,4\% и 2), Партия центра (10,8\% и 2$)$, христианские демократы (8,7\% и 2), Левая партия (6,7\% и 1$)$ и либералы $(4,1 \%$ и 1$)$. Феминистская инициатива получила лишь $0,8 \%$ и не прошла в Европарламент.

Таким образом, результаты выборов свидетельствуют, что доля голосов, поданных за крупнейшие традиционные партии - социал-демократов и умеренно-коалиционную партию на выборах в Европейский парламент обычно ниже, чем на выборах в риксдаг. Демократы Швеции также получили меньше голосов, чем на выборах в риксдаг в 2018 г. Напротив, зелёные получили намного больше голосов в Европарламент, чем в риксдаг.

Явка составила 54,65\% (в целом по ЕС - 50,93\%), что оказалось самым высоким показателем за всё время участия Швеции в ЕС. Но всё же эта высокая явка уступает явке на последних парламентских выборах 2018 г., где она составила 84,5\%.

По сравнению с предыдущими выборами произошли некоторые подвижки. Потери были у зелёных (-4\% голосов и 2 места), либералов (-5,8\% и 1) и Феминистской инициативы ($4,7 \%$ и 1$)$, а приобрели дополнительно по одному месту Демократы Швеции (+6,3\% голосов), Умеренно-коалиционная партия $(+3,1 \%)$, Партия центра $(+4,3 \%)$ и христианские демократы $(+2,8 \%)$.

Таблица 1

Швеция. Результаты выборов в Европарламент и в риксдаг (места и \%)

\begin{tabular}{|c|c|c|c|c|}
\hline Партии & $\begin{array}{c}\text { Европарламент } \\
2014 \text { г. (места, \%) }\end{array}$ & $\begin{array}{c}\text { Риксдаг } \\
2014 \text { г. }\end{array}$ & $\begin{array}{c}\text { Риксдаг } \\
2018 \text { г. }\end{array}$ & $\begin{array}{c}\text { Европарламент } 2019 \text { г. } \\
(\text { места, \%) }\end{array}$ \\
\hline СДРПШ & $5 \quad 24,2$ & 31,2 & 28,4 & $5 \quad 23,6$ \\
\hline Зелёные & 15,4 & 6,8 & 4,3 & 11,4 \\
\hline Умеренно-коалиционная партия & 13,7 & 23,2 & 19,8 & 16,8 \\
\hline Либералы & 9,9 & 5,4 & 5,5 & 4,1 \\
\hline Демократы Швеции & 9,7 & 12,9 & 17,6 & 15,4 \\
\hline Партия центра & 6,5 & 6,1 & 8,6 & 10,8 \\
\hline Левая партия & 6,3 & 5,7 & 7,9 & 6,7 \\
\hline Христианско-демократическая партия & 5,9 & 4,6 & 6,4 & 8,7 \\
\hline Феминистская инициатива & 5,5 & - & - & 0,8 \\
\hline
\end{tabular}

В Финляндии большое влияние оказали выборы в национальный парламент, которые прошли примерно за полтора месяца до выборов в Европарламент (см. табл. 2).

Финляндия. Результаты выборов в Европарламент и эдускунту (места и \%)

\begin{tabular}{|c|c|c|c|c|}
\hline Партии & $\begin{array}{c}\text { Европарламент } 2014 \text { г. } \\
(\text { места, \%) }\end{array}$ & $\begin{array}{l}\text { Эдускунта } \\
2015 \text { г. }\end{array}$ & $\begin{array}{l}\text { Эдускунта } \\
2019 \text { г. }\end{array}$ & $\begin{array}{c}\text { Европарламент } 2019 \text { г. } \\
\text { (места, \%) }\end{array}$ \\
\hline Национальная коалиционная партия & 322,6 & 18,2 & 17,0 & 320,8 \\
\hline Партия центра & 19,7 & 21,1 & 13,8 & 13,5 \\
\hline Истинные финны & 12,9 & 17,6 & 17,5 & 13,8 \\
\hline Социал-демократическая партия & 12,3 & 16,5 & 17,7 & 14,6 \\
\hline Зеленый союз & 9,3 & 8,5 & 11,5 & 16,0 \\
\hline Союз левых сил & 9,3 & 7,1 & 8,2 & 6,9 \\
\hline Шведская народная партия & 6,8 & 4,9 & 4,5 & 6,3 \\
\hline
\end{tabular}

Научно-аналитический вестник ИЕ РАН, 2019, №3 
Вряд ли стоило ожидать от этих выборов каких-либо драматических изменений. Максимум, что могло произойти, это увеличение или уменьшение количества мандатов на одну единицу. Так и произошло. На некоторый рост голосов могли рассчитывать социал-демократы, «Истинные финны», которые пережили раскол в 2017 г., и особенно Зелёный союз. По опросам газеты Helsingin Sanomat до выборов, наиболее популярными кандидатами в Европарламент являлись Вилле Ниинистё и Хейди Хаутала от Зелёного союза, Эеро Хейнялуома от социал-демократов и Сари Эссайя от христианских демократов.

В 2019 г. в Финляндии победила, как и за пять лет до этого, Национальная коалиционная партия с 20,8\% голосов и 3 местами, за ней следовали Зелёный союз (16\% и 2), социалдемократы (14,6\% и 2), «Истинные финны» (13,8\% и 2), Партия центра (13,5\% и 2), Союз левых сил $(6,9 \%$ и 1) и Шведская народная партия (6,3\% и 1). Христианско-демократическая партия, набрав 4,9\% голосов, осталась без мандата в Европарламенте.

Национальная коалиционная партия, зелёные и Шведская народная партия на выборах в Европарламент традиционно получают больше голосов, чем на общенациональных выбоpax, а социал-демократы и «Истинные финны», наоборот, набирают больше голосов на выборах в Эдускунту.

Явка составила 40,7\%, что оказалось самым высоким показателем после выборов 1996 г. Явка на парламентских выборах в апреле 2019 г. была намного выше и составила 72,8\%.

Таким образом, в Финляндии была показана высокая стабильность результатов по сравнению с предыдущими выборами. Наиболее серьёзный урон понесла Партия центра, потеряв 6,2\% голосов и 1 мандат, а наибольший прирост оказался у Зелёного союза $(+6,7 \%$ и 1 мандат). Изменение процента голосов у остальных партий на превысило 2-3\%.

В Дании на выборах в Европарламент 2014 г. участвовало в 1,5 раза меньше избирателей (2277 тыс.), чем на выборах в фолькетинг (3519 тыс.).

Дания. Результаты выборов в Европарламент и фолькетинг (места и \%)

\begin{tabular}{|c|c|c|c|}
\hline Партии & $\begin{array}{c}\text { Европарламент } 2014 \text { г. } \\
(\text { места, \%) }\end{array}$ & Фолькетинг 2015 г. & $\begin{array}{c}\text { Eвропарламент } 2019 \text { г. } \\
\text { (места, \%) }\end{array}$ \\
\hline Датская народная партия & $4 \quad 26,6$ & 21,1 & $\begin{array}{ll}1 & 10,7\end{array}$ \\
\hline Социал-демократическая партия & $3 \quad 19,1$ & 26,3 & 21.5 \\
\hline Венстре & 16,7 & 19,5 & 23,5 \\
\hline Социалистическая народная партия & 11,0 & 4,2 & 13,2 \\
\hline Консервативная народная партия & 19,1 & 3,4 & 6,2 \\
\hline Движение против ЕС & 8,1 & - & 3,7 \\
\hline Либералы & 6,5 & 7,5 & 2,2 \\
\hline Красно-зелёный альянс & & 7,8 & 5,5 \\
\hline Альтернатива & & 4,8 & 3,4 \\
\hline Радикальная Венстре & & 4,5 & 10,1 \\
\hline
\end{tabular}

В 2019 г. в Дании победила Венстре с 23,5\% голосов и 3 местами, за ней следовали социал-демократы (21,5\% и 3), Социалистическая народная партия (13,2\% и 2), Датская народная партия (10,7\% и 1), Радикальная Венстре (10,1\% и 2), Консервативная народная партия (6,2\% и 1) и красно-зелёный альянс (5,5\% и 1). Движение против ЕС (3,7\% голосов), Альтернатива $(3,4 \%)$ и Либеральный альянс $(2,2 \%)$ не прошли в Европарламент.

На выборах в Европарламент заметно больше голосов получила Социалистическая народная партия, чем на выборах в фолькетинг, а социал-демократы, напротив, больше голосов набирали на выборах в фолькетинг. Среди остальных партий трудно выявить какую-либо тенденцию к увеличению или уменьшению их влияния.

Явка на выборах в ЕП в Дании составила $66 \%$, что оказалось самым высоким показате-

Научно-аналитический вестник ИЕ РАН, 2019, №3 
лем, начиная с выборов 1979 г. Этот высокий показатель свидетельствует о повышении интереса датских избирателей к данным выборам. И всё же явка на выборах в фолькетинг 5 июня 2019 г. оказалась намного выше $-84,5 \%$.

В Дании произошли наиболее радикальные изменения. Датская народная партия потерпела сокрушительное поражение, потеряв 15,9\% голосов и 3 из 4 мест в Европарламенте. Потеряли свои мандаты Движение против ЕС (-4,4\%) и либералы $(-4,3 \%)$. В числе победителей оказались партия Венстре $(+6,8 \%)$, Социалистическая народная партия $(+2,2 \%)$, красно-зелёный альянс, которые получили по одному дополнительному месту, а Радикальная Венстре получила два места в Европарламенте.

Таким образом, картина перемен на Севере Европы весьма различна. В Финляндии изменения оказались минимальными: лишь 1 мандат перешёл к другой партии. В Швеции мандаты поменяли своих владельцев в четырёх случаях. В Дании произошли наиболее значительные перемены. Мандаты поменяли своих владельцев в пяти случаях, при этом одна из партий потеряла 3 места в Европарламенте, а другие партии вообще покинули его.

В целом выборы в Европейский парламент, которые состоялись 26 мая 2019 г., внесли определённую ясность в расклад политических сил в Швеции, Финляндии и Дании. Переоценивать итоги этих выборов не следует, поскольку интерес к ним традиционно находится на более низком уровне по сравнению с выборами в национальные парламенты. Более весомую роль в них могли сыграть крайне правые популистские партии, которые ориентируются в основном на евроскептиков и протестные группы электората. Однако, как и в целом в странах Евросоюза, драматических изменений в северных странах и резкого усиления правых популистов не произошло.

\section{The results of elections to European parliament 2019 in the Nordic countries: Statistics}

Author. Alexey Volkov, Candidate of Sciences (Economics), Head of the Section of Economics of European Countries in the Centre of European Studies, Primakov National Research Institute of World Economy and International Relations, Russian Academy of Sciences. Address: 23, Profsoyuznaya str., Moscow, Russia, 117997. E-mail: volkov@imemo.ru.

Abstract. The elections to the European Parliament are interesting phenomena for the Nordic countries: Sweden, Finland and Denmark. The economic situation in the Nordic countries in 2019 is a generally favorable background for these elections. Despite the sparse population and the small number of seats that the Nordic countries have in the European Parliament, the elections showed certain balance of internal political forces as of May 2019. Elections in Finland were especially stable, the greatest changes occurred in Denmark.

Keywords: elections, Europarliament, Sweden, Finland, Denmark.

DOI: http://dx.doi.org/10.15211/vestnikieran320193035 